\title{
¿Solo informar o también persuadir? Museos y publicidad en España
}

\author{
Santos M. MATEOS RUSILlO ${ }^{1}$ \\ Universitat de Vic
}

\begin{abstract}
RESUMEN:
Este artículo explora la actual relación de la publicidad convencional con los museos de arte españoles, presentando los dos modelos existentes: el que sólo se preocupa por informar y otro que explora y explota las posibilidades del lenguaje publicitario. El primero, mayoritario, fortalece la excepcionalidad del ámbito cultural, mientras que el segundo, muy minoritario, demuestra con sus excepciones que es posible aplicar la creatividad en la publicidad producida para posicionar a los museos españoles y promocionar sus actividades.
\end{abstract}

PALABRAS CLAVE: Publicidad; comunicación; España; museo de arte.

TITLE: Just inform or also persuade? Museums and advertising in Spain.

ABSTRACT: This article explores the current relation between conventional advertising and Spanish art museums presenting the two existing models: the one that only informs, and the other that explores and exploits the possibilities of the language of advertising. The former, a majority, strengthens the exceptionality of the cultural field, while the latter, a minority, proves with its exceptions that it is possible to use creativity in the advertising produced with the objective of positioning the Spanish museums and promoting their activities.

KEY WORDS: Advertising; communication; Spain; art museum.

No tardaremos en poder vivir sin publicidad, así que tenemos que crear anuncios interesantes, anuncios que la gente quiera ver

Oliver Voss

\section{Museos \& Pub: una relación necesaria}

Hablar hoy día del «museo» es hacerlo de su público (usuarios o visitantes), tanto el real como el potencial. Basta con mirar cómo ha evolucionado la propia definición de esta institución cultural propuesta por el Consejo Internacional de Museos (ICOM). ${ }^{2}$ Desde una primera aproximación en 1946, donde no se hacía

1 Profesor del departamento de Comunicación (Facultad de Empresa y Comunicación), donde imparte Historia del Arte, Evolución de las ideas estéticas y Comunicación del Patrimonio cultural. Coordinador del Grupo de Investigación en Comunicación y Patrimonio (GRECOPA).Correo electrónico: santos.mateos@uvic.cat

2 El ICOM, creado en 1946, es la organización intergubernamental de referencia en el mundo de los museos. Tiene una relación formal con la UNESCO y estatus de órgano consultivo del Consejo Económico y Social de las Naciones Unidas. 
ningún tipo de referencia a su vocación de servicio a la sociedad, hasta la actual adoptada en 2007, donde esta cuestión es fundamental:

A museum is a non-profit, permanent institution in the service of society and its development, open to the public, which acquires, conserves, researches, communicates and exhibits the tangible and intangible heritage of humanity and its environment for the purposes of education, study and enjoyment. ${ }^{3}$

Hablar del «museo» del siglo XXI es también hacerlo de una institución dinámica, capaz de generar actividades culturales de forma continua y sostenida, potencialmente interesantes para su público, tales como exposiciones temporales, ciclos de conferencias, talleres didácticos, etc.

Ya nadie duda que el museo y las actividades que genera sean fundamentales para la buena salud cultural y educacional de la sociedad. ${ }^{4}$ Pero para que realmente sean indicadores de buena salud, como comenta Valdés, «el personal del museo tiene el deber de dar a conocer la existencia de esta institución y de sus colecciones de la forma más adecuada para los distintos segmentos de público. Por su parte, el público tiene el derecho a visitar y comprender el museo, a ser informado convenientemente, para estar en la situación de decidir libremente si lo visita o no». ${ }^{5}$

Pero, ¿qué pasa cuando esos usuarios potenciales tienen una imagen equivocada o sesgada del museo o no llegan a saber de las actividades programadas? O ¿qué pasa cuando se les informa de manera poco efectiva? La respuesta es inequívoca: fracaso.

Y la solución para que el fracaso se torne en éxito es muy sencilla: la configuración de una estrategia de comunicación y la utilización de las técnicas y soportes comunicativos capaces de conectarlos de forma efectiva con el público potencialmente interesado. Técnicas entre las que se encuentra la publicidad.

Aunque a nadie le sorprende ya escuchar los vocablos marketing, merchandising, producto o publicidad asociados a la institución museística, muy distinto es que su maquinaria interna (directivos, conservadores, restauradores...) los acepte no sin reticencias (cuando no con desprecio). Y si alguna técnica comunicativa tiene mala fama en el mundo de los museos (y de la cultura en general) es la publicidad. Algo paradójico, pues constituye en sí misma una muestra cultural de nuestra época, parte de nuestro patrimonio cultural. ${ }^{6}$

Minusvalorada o no, la realidad es que los museos españoles necesitan de la publicidad (y viceversa, como se verá al final de este artículo) para alcanzar y cum-

\footnotetext{
3 ICOM (2010): «Development of the Museum Definition according to ICOM Statutes (20071946)», http://icom.museum/hist_def_eng.html. Web visitada el 01/04/2010.

4 HOOPER-GreENHILl, E. (1994): Los museos y sus visitantes, Gijón, Ediciones Trea, 1998, 236.

5 VALDÉS-SAGÜES, M. C. (1999): La difusión cultural en el museo: servicios destinados al gran público, Gijón, Ediciones Trea, 236.

6 GUIRAO, Á. (2006): «广Forma parte la publicidad de nuestro patrimonio cultural? (Publicidad y Patrimonio)», Tonos Digital. Revista electrónica de estudios filológicos, n. 11, http://www.um.es/tonosdigital/znum11/estudios/10-publicidad.htm. Web visitada el 02/04/2010.
} 
plir, de forma eficaz, con la misión cultural y social que tienen encomendados en nuestra sociedad contemporánea. Porque lo importante de la publicidad, como decía Walter Benjamin, no es lo que dicen los huidizos caracteres rojos del letrero luminoso, sino el charco de fuego que los refleja en el asfalto ${ }^{7}$, la impronta que es capaz de conseguir en la mente del receptor.

De hecho, la mayoría de museos españoles, ya sean los buques insignia como el Museo Nacional del Prado, el Museo Guggenheim de Bilbao o el Museu Nacional d'Art de Catalunya, o los de mediano o pequeño formato, se sirven de la publicidad para que su público sepa de su vida institucional y de sus actividades. Algunos de forma continuada y otros, los más pequeños y con menos recursos, de forma puntual. Es decir, existe una inversión publicitaria sostenida e importante.

Si bien antes era suficiente con informar, ahora ya ha dejado de ser lo más efectivo en la mayoría de situaciones. Cada vez existe más competencia (y sólo hablamos de la competencia de otros equipamientos culturales) que sobresatura informativamente los canales comunicativos. Los potenciales usuarios tenemos cada vez más oferta cultural donde elegir para disfrutar de nuestro tiempo de ocio, oferta sobre la que recibimos multitud de impactos publicitarios ${ }^{8}$. La mera información pasa inadvertida voluntariamente. Pasamos la página sin percatarnos de aquel anuncio que nos informa de manera anodina de una nueva exposición, o ni siquiera alzamos la vista cuando nos encontramos algo parecido en una banderola. En general, solo nos detenemos por unos segundos delante de un anuncio cuando nos sorprende. Parafraseando a un histórico del diseño gráfico de entreguerras, Cassandre, solo le prestamos atención cuando el anuncio es capaz de provocar sorpresa, violentar la sensibilidad y señalar la memoria con una huella indeleble?

Lo que antes funcionaba, en muchos casos dejó de hacerlo hace tiempo. Se trata de un nuevo escenario que obliga a plantearse las cosas de forma diferente. Y la brújula para transitar por el nuevo camino también se encuentra en la misma publicidad. En una publicidad seductora, persuasiva ${ }^{10}$, sugerente y, sobre todo, inteligente; capaz de generar mensajes eficaces que captarán la atención, mantendrán el interés, despertarán el deseo e inducirán a la acción ${ }^{11}$.

Pero que nadie se lleve a engaño. Tampoco se trata que toda la publicidad tenga que seguir necesariamente esta tendencia, pues todo depende de la imagen de marca del

\footnotetext{
7 Benjamin, W. (1955): Dirección única, Madrid, Ediciones Alfaguara, 1987, 77.

8 Según algunos cálculos, sólo es creído entre un 5 y un 10 por 100 de todos los mensajes publicitarios, mientras el restante 90 o 95 por 100 no es visto/escuchado o creído. EGUIZÁBAL, R. (2007): Teoría de la publicidad, Madrid, Ediciones Cátedra, 131.

9 Citado en SAtué, E. (2004): El diseño gráfico. Desde los orígenes hasta nuestros días, Madrid, Alianza Editorial, 230.

10 Como decía José Ortega y Gasset, «Para persuadir, primero hay que seducir». Citado en FeRNÁNDEZ LóPEZ, S. (2007): Cómo gestionar la Comunicación. En organizaciones públicas y no lucrativas, Madrid, Narcea, 223.

11 Kotler, N.; Kotler, P. (1998): Estrategias y marketing de museos, Barcelona, Editorial Ariel, 2001, 265.
} 
museo, del objeto a publicitar, del público al que se dirige, etc., lo que puede derivar en determinados casos en la necesidad de servirse de la publicidad denotativa.

Por ejemplo, al Museo Nacional del Prado, con una identidad institucional ${ }^{12}$ que le ha permitido generar una imagen de marca clara, sólida y consolidada (calidad, elegancia, sobriedad, etc.), seguramente le sea más que suficiente con informar a su target group de una nueva exposición, utilizando para ello una gráfica totalmente informativa (Fig. 1). Incluso, en casos como el de la pinacoteca madrileña, es muy probable que se ocasionase un efecto negativo de utilizarse una publicidad persuasiva, lesionando peligrosamente esa monolítica imagen de marca de la que goza actualmente.

Fig. 1. Muestra de publicidad exterior del Prado

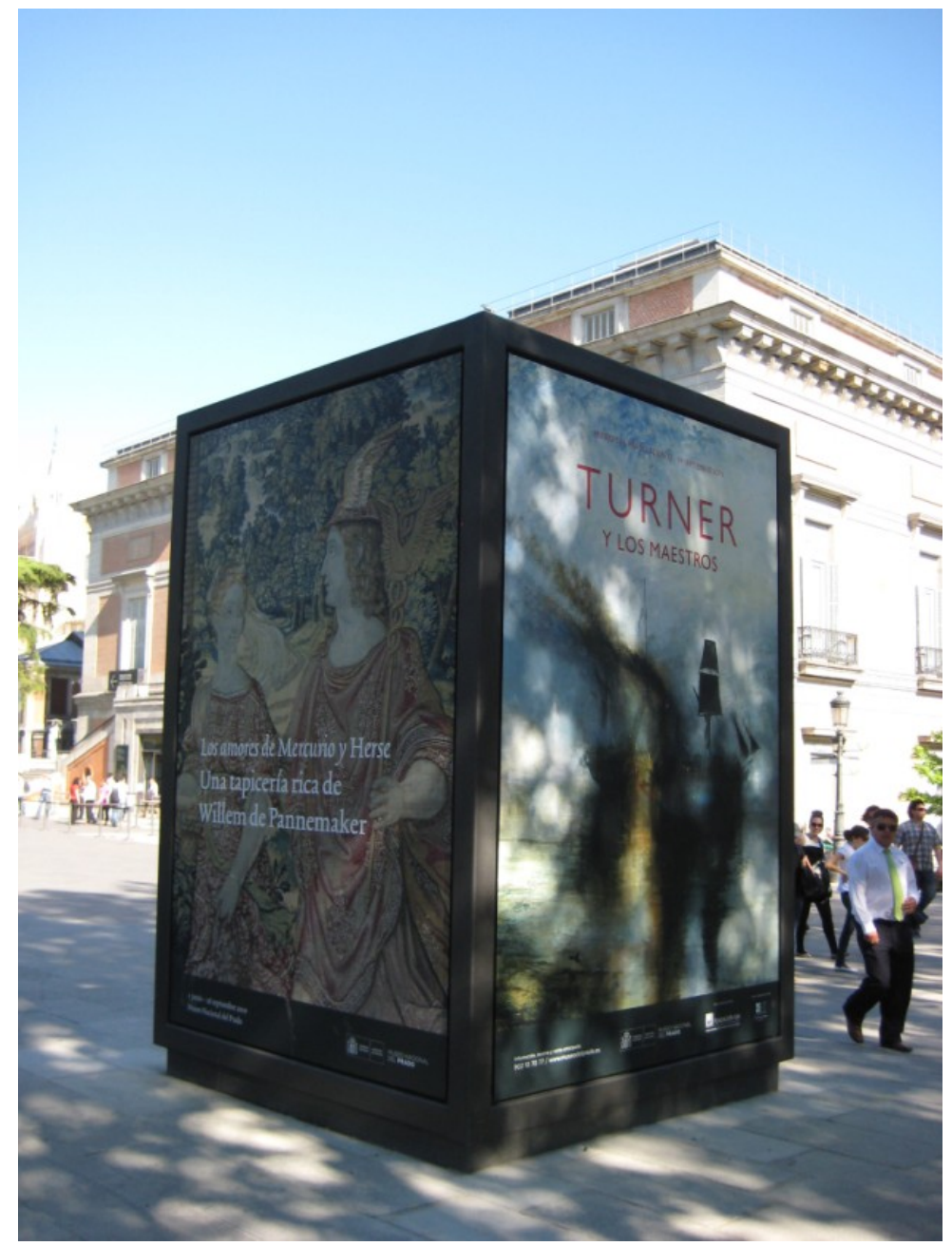

Fuente: elaboración propia.

12 Que le permite comunicar su valiosa herencia artística, al mismo tiempo que le sitúa como una institución del siglo XXI. Hyland, A.; KING, E. (2006): c/id. Cultura e identidad. El arte de las marcas, Barcelona, Blume, 106-111. 


\section{El panorama actual: la excepcionalidad del mundo cultural}

\section{Excepcionalidad: Cualidad de excepcional.}

Excepcional: Que constituye excepción de la regla común $\left[1^{a}\right.$. acepción del diccionario de la RAE].

Por simple tradición, ahora ya por pura inercia, el ámbito cultural supone una excepcionalidad en cuanto a la aplicación de la creatividad publicitaria.

De los dos grandes regímenes-tipo de la retórica publicitaria, informativodenotativo y persuasivo-connotativo ${ }^{13}$, prácticamente toda la publicidad que se produce para promocionar la cultura responde al primero de los niveles: el informativo-denotativo: sólo se preocupa por informar al público potencial.

Y si utilizamos un microscopio para escrutar el sector de la cultura, seguramente el mundo de los museos y atractivos patrimoniales sea uno de los sectores donde se cumple con más empeño, condenando a la publicidad «al manejo de un breve repertorio de cliché» ${ }^{14}$ que la retorna a su prehistoria, cuando bastaba con utilizar un lenguaje convencional solo preocupado y ocupado por informar.

Basta con ojear las secciones o suplementos culturales de la prensa escrita (Figs. 2 y 3) o divisar alguna muestra de publicidad exterior (Fig. 4) para toparse con alguna muestra de este tipo mayoritario de publicidad informativa. La solución es muy sencilla: una imagen de fondo de alguna de las piezas que forman parte de la exposición o de una toma significativa de las instalaciones del museo y la información textual básica (nombre, fechas, dirección, etc.).

Piezas publicitarias tras las cuales hay un laborioso trabajo para alcanzar una óptima resolución gráfica (aunque sorprende todavía encontrarse con auténticos «monstruos del diseño», como los llamaba el director de arte Gabriel Díaz Meyer). Por ejemplo, sabemos del laborioso trabajo que conduce a la selección de la imagen de la obra sobre la que pivotará todo el concepto gráfico de una campaña publicitaria para promocionar una exposición temporal ${ }^{15}$. Algo que se puede hacer extensible a la elección de la tipografía, de los colores, a la distribución del material gráfico, etc. Muestras que, sin embargo, carecen de la participación y presencia del lenguaje publicitario, lo que las aleja, y mucho, de aquella visión que tenían de la publicidad Henry Fielding y Gilles Lipovetsky, el primero como «arte de la persuasión», el segundo como «apoteosis de la seducción».

13 Ricarte, J. M. (1998): Creatividad y comunicación persuasiva, Barcelona, Universitat Autònoma de Barcelona, Servei de Publicacions et alt., 82.

14 EguizÁBAL, R. (2007), op. cit., 25.

15 BAENA, M. (2009): «Salvaje (fauve) es la palabra que mejor define la campaña de comunicación de la exposición Kees Van Dongen pero, ¿cómo se llega a la elección de la imagen que será su leit motiv?», El Blog del Museu Picasso de Barcelona, http://www.blogmuseupicassobcn.org/es/2009/07/salvaje-fauve-es-la-palabra-que-mejor-define-lacampana-de-comunicacion-de-la-exposicion-kees-van-dongen-pero-\%c $\%$ bfcomo-se-llega-a-laeleccion-de-la-imagen-que-sera-su-leit-motiv/. Web visitada el 02/04/2010. 
Figs. 2 y 3. Muestras de publicidad en prensa
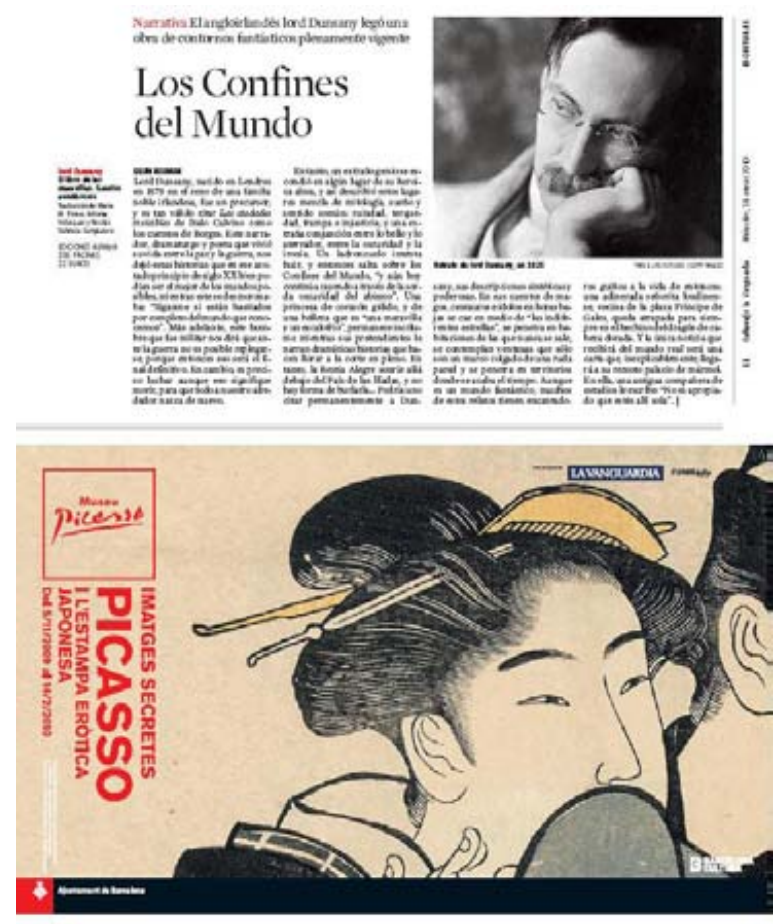

La vitamina C no previene la gripe pero puede acelerar su curación

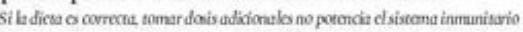
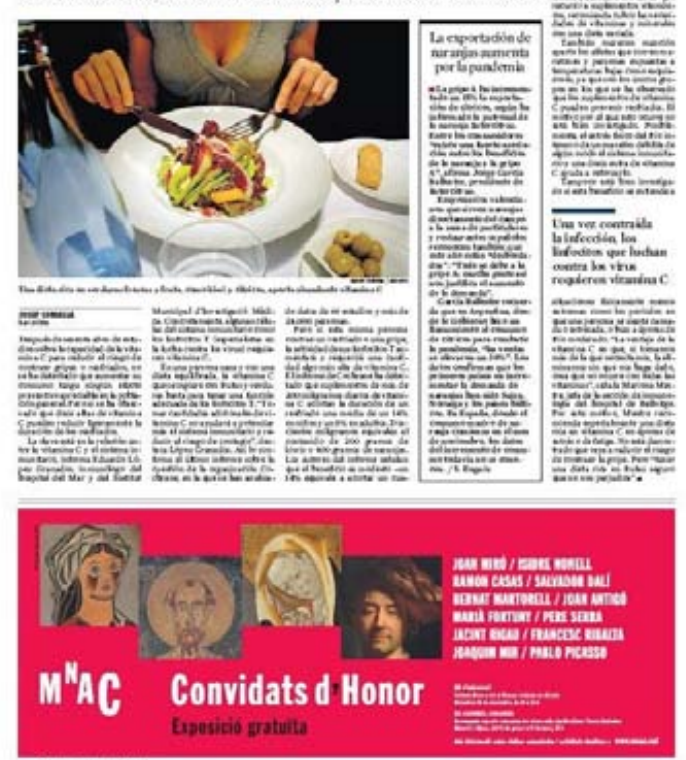

75 표틀

Fuente: La Vanguardia.

Fig. 4. Muestra de publicidad exterior

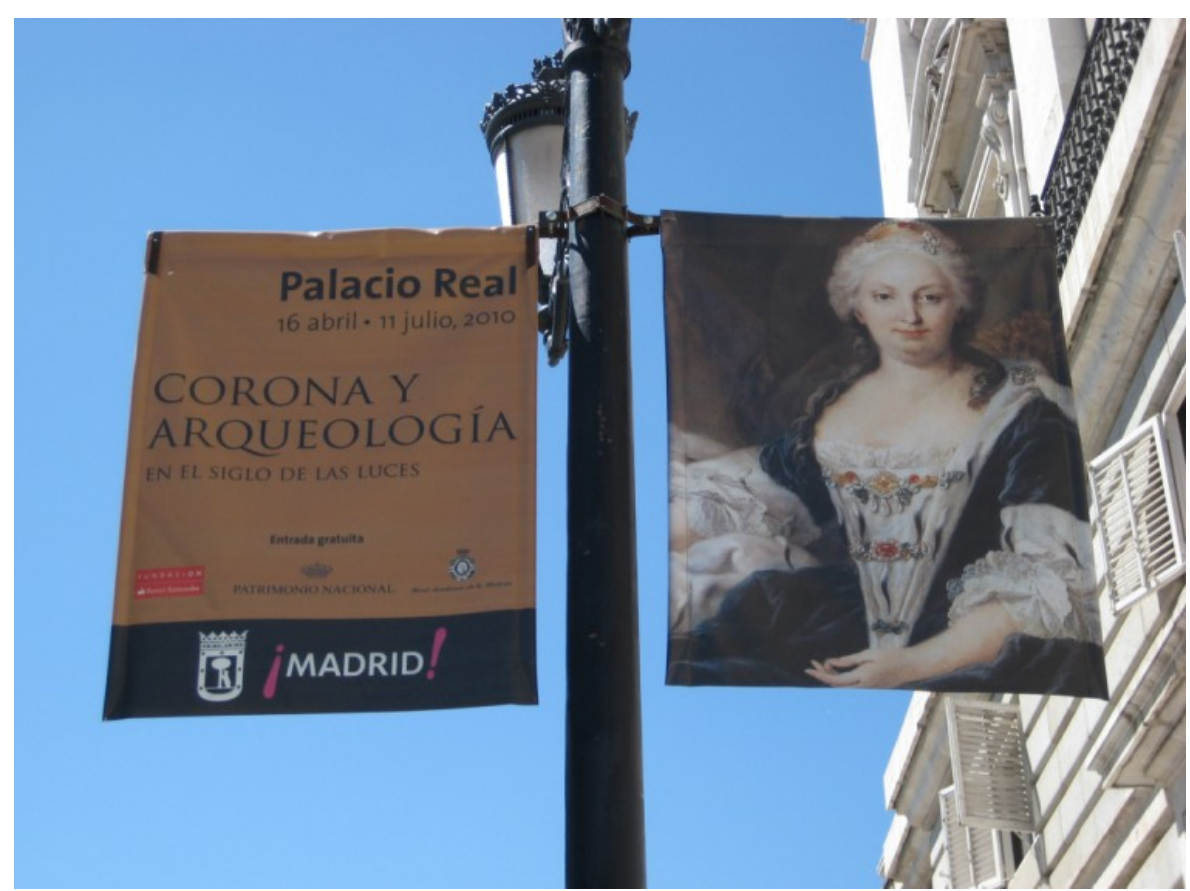

Fuente: elaboración propia. 
¿A qué es debido este panorama desértico?

Una primera posibilidad tiene que ver con la importancia concedida a la comunicación en nuestros museos. Aunque a nivel teórico nadie duda en considerarla una variable estratégica para cumplir con su misión ${ }^{16}$, lo cierto es que en la praxis se entiende mayoritariamente como una cuestión puramente táctica, de aplicación puntual. Se elabora la actividad cultural (el producto) sin partir de la misión, sin tener claro los públicos y su necesaria segmentación, pidiéndose en última instancia que el responsable de comunicación de turno se encargue de comunicarlo (normalmente con poco tiempo como para pensar en campañas de una cierta enjundia y complejidad). Esta manera de proceder táctica, donde la planificación estratégica brilla por su ausencia, genera desajustes importantes. Por ejemplo, que la actividad planteada (pongamos por caso unos talleres didácticos) nos lleve directamente al público objetivo (que para el caso sería el público infantil), cuando lo correcto es que fuese a la inversa: el museo considera estratégico fortalecer su relación con el público infantil para cumplir mejor con su misión, lo que conduce a la decisión de diseñar unos talleres didácticos ${ }^{17}$.

Visión táctica directamente conectada con el escaso respeto que se tiene por los profesionales que se dedican a la comunicación: parece ser que en el resto de departamentos todos tienen originales ideas para crear el concepto creativo de una campaña (todos son creativos), todos saben muy bien cuál es la mejor tipografía o el mejor color (todos son diseñadores), como también todos saben cómo organizar textos e imágenes para crear anuncios impactantes (todos son directores de arte). Cuando a ningún profesional de la comunicación se le ocurre refutar la atribución de una obra hecha por un conservador o sugerir a un restaurador la utilización de un determinado producto químico para restaurar una obra, tanto conservadores como restauradores sí se ven capacitados para opinar sobre algo que desconocen.

Otra posible respuesta tiene que ver con quién acaba conceptualizando y materializando las piezas publicitarias. Una porción muy significativa de la publicidad de los museos se encarga a directores de arte o diseñadores, travistiendo el proceso publicitario canónico de concepción-materialización: alguien conocedor del lenguaje publicitario, el creativo, tiene la idea que conduce al concepto; que se visualizará y materializará gráficamente gracias a la labor de otro profesional, el director

16 Basta con mirar documentos como GARDE, V.; IZQUIERDO, I. (coord.) (2005): Criterios para la elaboración del Plan Museológico, Madrid, Subdirección General de Museos Estatales, Dirección General de Bellas Artes y Bienes Culturales, Ministerio de Cultura,

$\mathrm{http}: / /$ www.mcu.es/museos/MC/PM, concretamente las páginas 40-41, 102-108 y 148-151. Web visitada el 02/04/2010.

17 Puig De la Bellacasa, B. (2006): «Segmentación de públicos y estrategias de comunicación cultural», en Gómez de la Iglesia, R., La comunicación en la gestión cultural, Vitoria-Gasteiz, Grupo Xabide, 46-47. 
de arte o diseñador. Y es que, como comenta Álvaro Gurrea, el diseño tiene tanto que ver con la publicidad como el empapelado de las paredes con la decoración ${ }^{18}$.

Sea por cualquiera de esas razones o por todas ellas juntas, lo curioso es que se prescinda de los creativos publicitarios, sin tener en cuenta que este ámbito cultural seguramente sea el idóneo para servirse de su inteligencia creativa a la hora de producir y comunicar significados amplificadores del valor social de los museos. No existe un sector más capacitado para movilizar emociones que el cultural (de hecho ese es su objetivo vital, su raison d'être). Por tanto, ¿por qué no servirse de la creatividad publicitaria para establecer esos vínculos emocionales con el público potencial?

\section{Oasis en el desierto: excepciones a la excepcionalidad}

Excepcional: Que se aparta de lo ordinario, o que ocurre rara vez $\left[2^{a}\right.$. acepción del diccionario de la RAE].

No siempre se cumple a rajatabla la excepcionalidad cultural que se acaba de exponer. Por suerte existen excepciones, pero como tales conforman una mínima porción de toda la producción publicitaria que se edita para promocionar museos y sus actividades. Pocas, pero suficientes como para poder demostrar que también es posible hacer una publicidad que vaya más allá de lo meramente informativo.

Una publicidad inteligente capaz de sorprender a los usuarios habituales. Una publicidad persuasiva capaz de movilizar a los potenciales usuarios. Haciéndolo, además, sin olvidar que ha de ser capaz de equilibrar intereses contrapuestos: despertar el interés de un nuevo público sin alejar a los consumidores habituales.

Vamos a ver a continuación alguna muestra actual (de anuncios en Internet, televisión, prensa y exterior) de ese reducido cupo excepcional, que puebla el planeta de las excepciones comunicativas a la hora de promocionar los museos y sus actividades. Se trata de piezas que bien merecen incluirse en este selecto club, por utilizar diferentes recursos creativos como el sentido del humor, la provocación, la acumulación de guiños inteligentes dirigidos a sus potenciales receptores o alguna figura retórica.

\subsection{Un ejemplo de utilización del humor}

El primer ejemplo que abre la serie es un banner interactivo y un espot televisivo. Tales piezas publicitarias servían para publicitar la actividad del Museu Nacional d'Art de Catalunya (Barcelona) «Jueves de verano en el MNAC» (la apertura del museo hasta la medianoche de los jueves estivales).

18 GurReA, Á. (1999): Los anuncios por dentro, Bilbao, Servicio Editorial de la Universidad del País Vasco, 246-247. 
La campaña, ideada por la agencia Bassat Ogilvy Barcelona y constituida por dos piezas publicitarias, se servía del humor (que podría calificarse de negro) como clave creativa.

Un banner animado interrogaba al usuario virtual, de una forma muy provocativa: ¿por donde entrar al museo por la noche? Para resolver la duda, se proponían tres posibilidades muy habituales entre los profesionales de lo ajeno: una escalera, un butrón o una tirolina (Fig. 5). Formas pocos usuales y peligrosas, pues en los tres casos se llamaba la atención de un furgón policial, de unos perros vigilantes o saltaban las alarmas. Y también innecesarias, pues, como se informaba al activar las puertas del edificio, el museo abría sus puertas por la noche (Figs. 6 y 7).

Figs. 5, 6 y 7. Capturas del banner animado de la campaña «Jueves de verano en el MNAC»
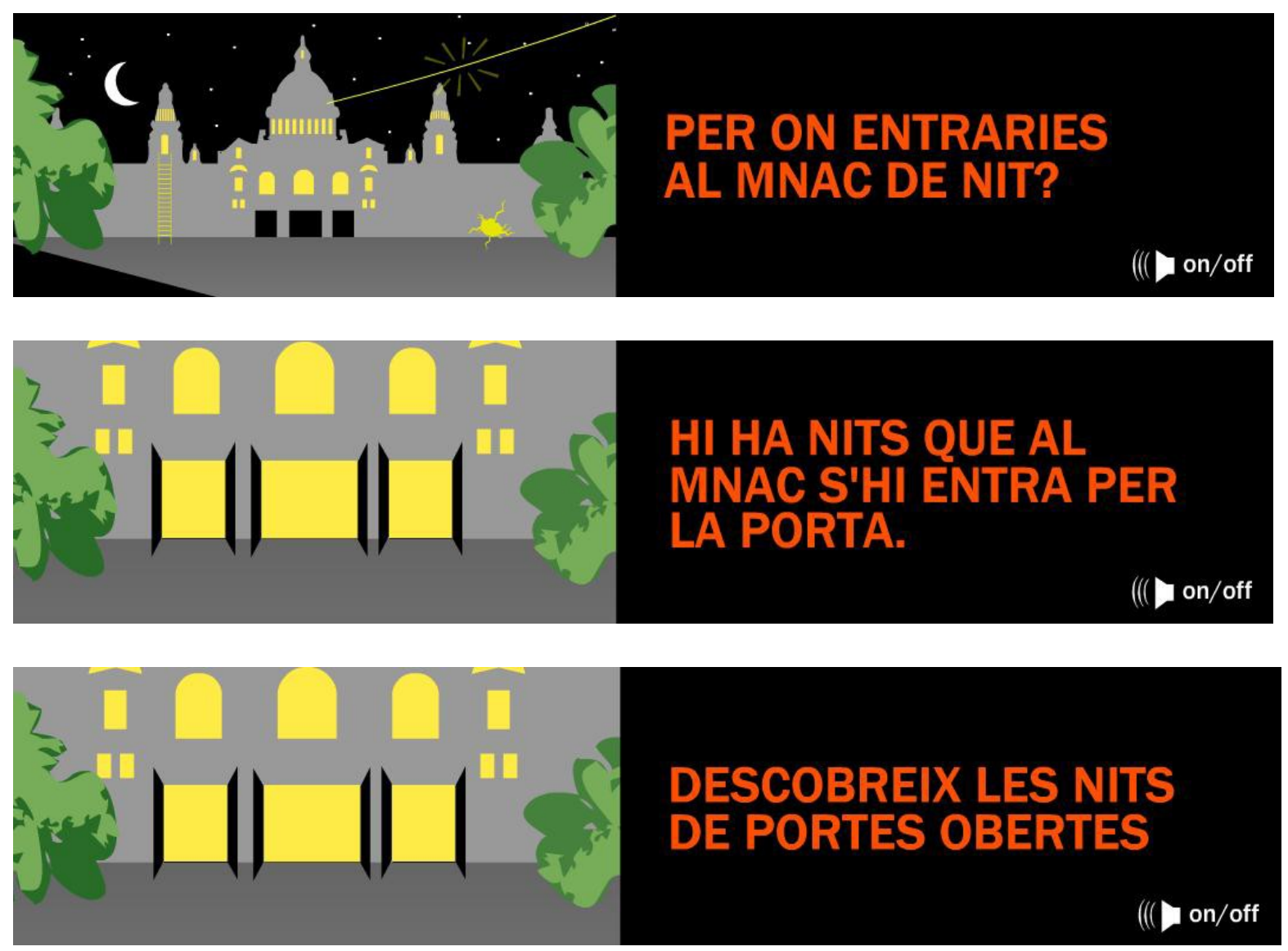

Fuente: MNAC

En el caso del cortometraje publicitario, titulado «Ladrón», los visitantes de una de las salas del museo disfrutan silenciosamente de las obras de Marià Fortuny allí expuestas (Fig. 8), cuando, repentinamente, se ven sorprendidos por la estruendosa y poco afortunada entrada en escena de un ladrón (Fig. 9), a su vez estupefacto y 
obviamente mal informado como para ser consciente de que aquella no era la mejor noche para trabajar.

Figs. 8 y 9. Fotogramas del espot de la campaña «Jueves de verano en el MNAC»
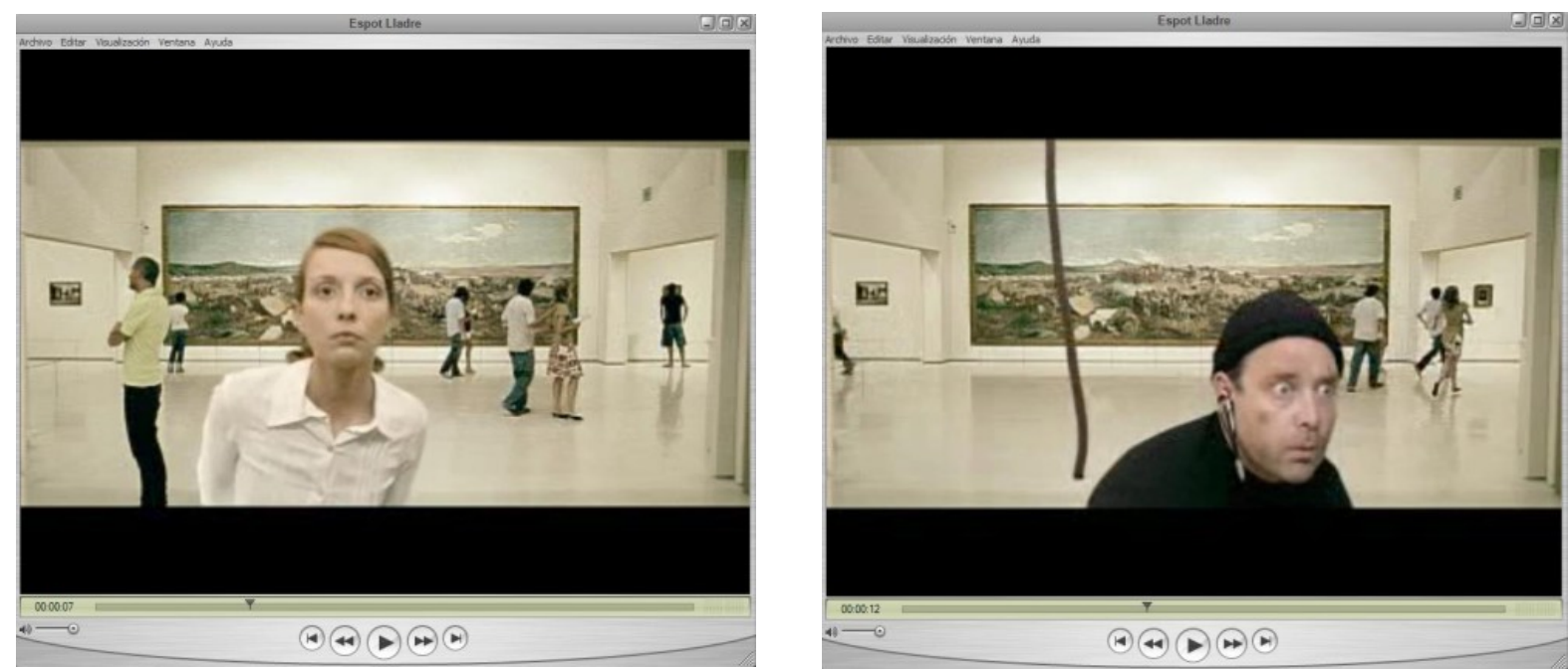

Fuente: MNAC

En resumen, una apuesta creativa muy valiente, pues al fin y al cabo se servía de un tema tabú en el mundo de los museos y colecciones de arte: el robo.

\subsection{Una muestra de utilización de la provocación}

Valiente fue también la propuesta publicitaria del Museo de Bellas Artes de Bilbao para promocionar la exposición temporal «El joven Murillo» (19 de octubre 2009-17 de enero 2010). Una exposición novedosa al mostrar al Murillo menos conocido: el de la etapa de formación (entre 1638-40 y 1650-53). Una muestra, comisariada por Alfonso Pérez Sánchez y Benito Navarrete, que pretendía matizar la idea generalizada del artista como pintor de vírgenes y temas religiosos. Para conseguirlo, mostraba la etapa en la que el sevillano abría taller propio, relacionándose estrechamente con los personajes que pueblan la literatura picaresca de nuestro Siglo de Oro.

En base a todas esas singularidades de la exposición a promocionar, la agencia guipuzcoana Herederos de Rowan realizó un cartel realmente sorprendente (Fig. 10).

La imagen, que utilizaba de base una de las obras estrella de la exposición (el «Autorretrato» del pintor, que se exponía por vez primera en España), fue mínimamente manipulada para introducirle una minúscula variación: un piercing en su ceja derecha (Fig. 11). 
Fig. 10. Cartel de la campaña «El joven Murillo»

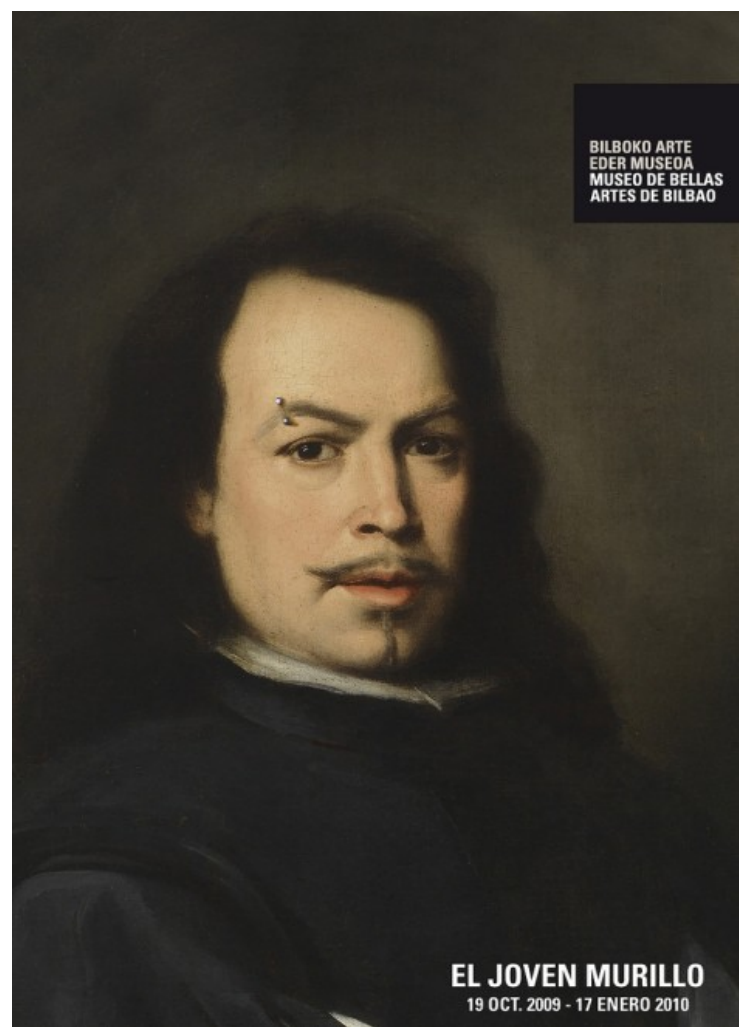

Fuente: Herederos de Rowan

Fig. 11. Detalle del cartel de la campaña «El joven Murillo»

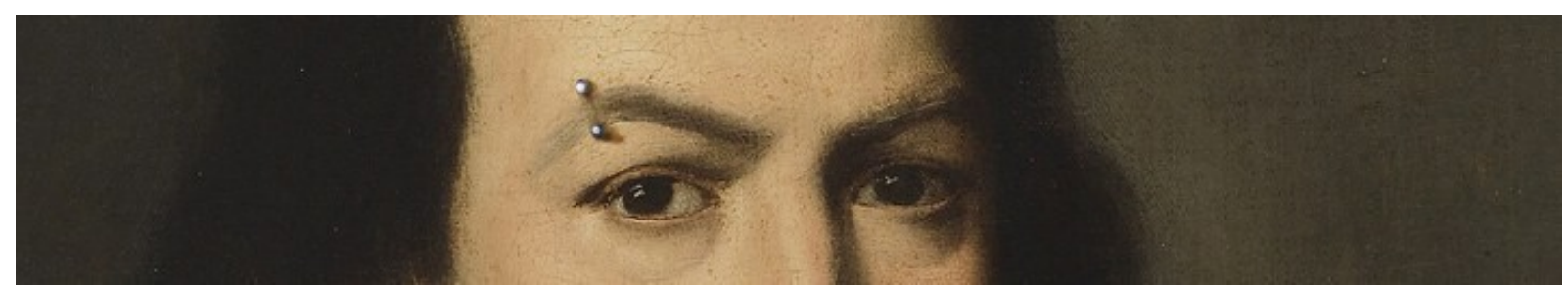

Fuente: Herederos de Rowan

Aunque mucha gente pensó y piense que se trataba de una provocación hueca, nada más lejos de la realidad. Era un guiño inteligente al título de la exposición, a su contenido y también al público más joven que podía estar interesado en la muestra. Uno de sus comisarios, Benito Navarrete, calificaba el cartel de «arriesgado y muy divertido ${ }^{19}$. Pero la historia no acaba aquí, pues no todos compartían esa opinión. Por desgracia, el coleccionista privado que había cedido la obra cuya imagen se había manipulado consideraba el anuncio de mal gusto, tanto que atentaba

19 Rondón, J. M. (2009): «Murillo con 'piercing'», elmundo.es, http://www.elmundo.es/elmundo/2009/10/03/andalucia_sevilla/1254567546.html. Web visitada el 25/05/2010. 
contra la pieza original. El resultado: por respeto al propietario, el museo consideró conveniente retirar la campaña.

Por supuesto, la polémica generó una amplia cobertura en medios de comunicación y en la blogosfera, consiguiendo una considerable publicity. Incluso, un periódico (el Diario de Sevilla) consideró oportuna la realización de una encuesta entre sus lectores virtuales ${ }^{20}$, a los que se planteaba la siguiente pregunta: «¿Está de acuerdo con la retirada del 'piercing' del cartel de la exposición del Joven Muri1lo?». Del total de 396 votos, estos fueron los porcentajes finales:

- un $29 \%$ opinaba "Sí, es una falta de respeto",

- un 3\% "Sí, hay que cumplir la legislación",

- un 39\% "No, no se debe coartar la creatividad",

- un $19 \%$ "No, es un gran cartel” y, por último,

- un $10 \%$ manifestaba no interesarle el tema.

En resumen, una gran mayoría de los encuestados (el 58\%) tenía una opinión favorable del cartel, bien por respetar la libertad creativa bien por considerarlo una buena pieza publicitaria.

Pero, más allá de encuestas y opiniones, el museo tuvo que plantear una nueva gráfica, cuyo resultado era una «campaña sin piercing» (Fig. 12). Se utilizaba la misma imagen de base, pero esta vez prescindiendo de cualquier manipulación.

Fig. 12. Cartel definitivo de la campaña «El joven Murillo»

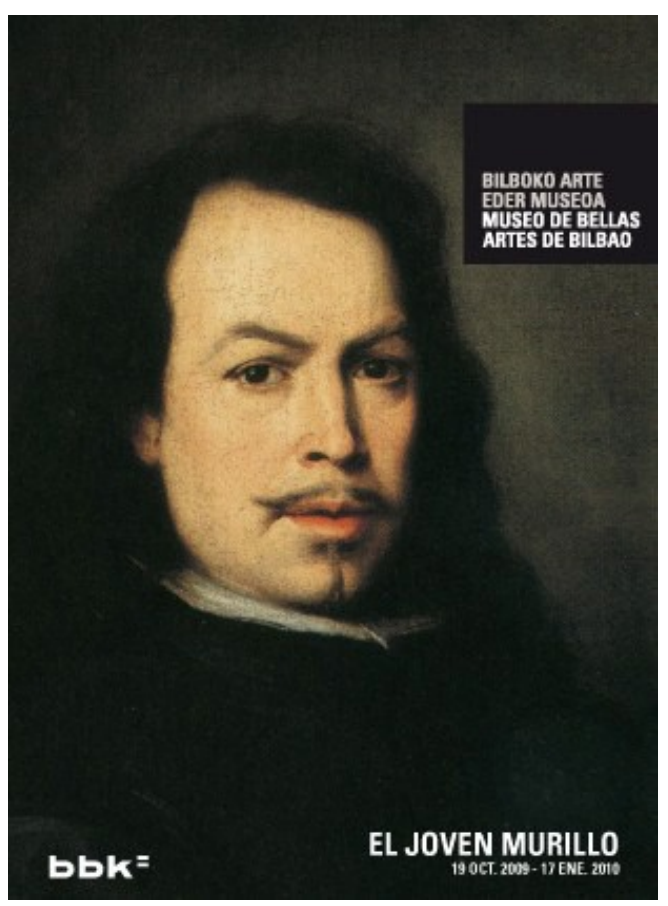

Fuente: Herederos de Rowan

20 Diario de Sevilla (2009): «¿Está de acuerdo con la retirada del 'piercing' del cartel de la exposición del Joven Murillo?», diariodesevilla.es, http://www.diariodesevilla.es/encuesta/?int PK=1777. Web visitada el 25/05/2010. 
Una pieza que respeta totalmente los cánones de la excepcionalidad comunicativa del ámbito cultural. Una nueva pieza que venía a engrosar el cupo de la publicidad informativa. Eso sí, que permitía respirar tranquilos a todos los implicados (coleccionista, comisarios, museo...).

\subsection{Un caso de utilización de guiños inteligentes}

El mismo tándem museo-agencia nos regaló otro magnífico cartel (Fig. 13) para promocionar la exposición «Balenciaga. El diseño del límite» (10 de mayo-26 de septiembre de 2010). Una gráfica realmente exquisita y llena de inteligentes guiños para los entendidos en moda y en la obra de Cristóbal Balenciaga.

Fig. 13. Cartel de la campaña «Balenciaga. El diseño del límite»

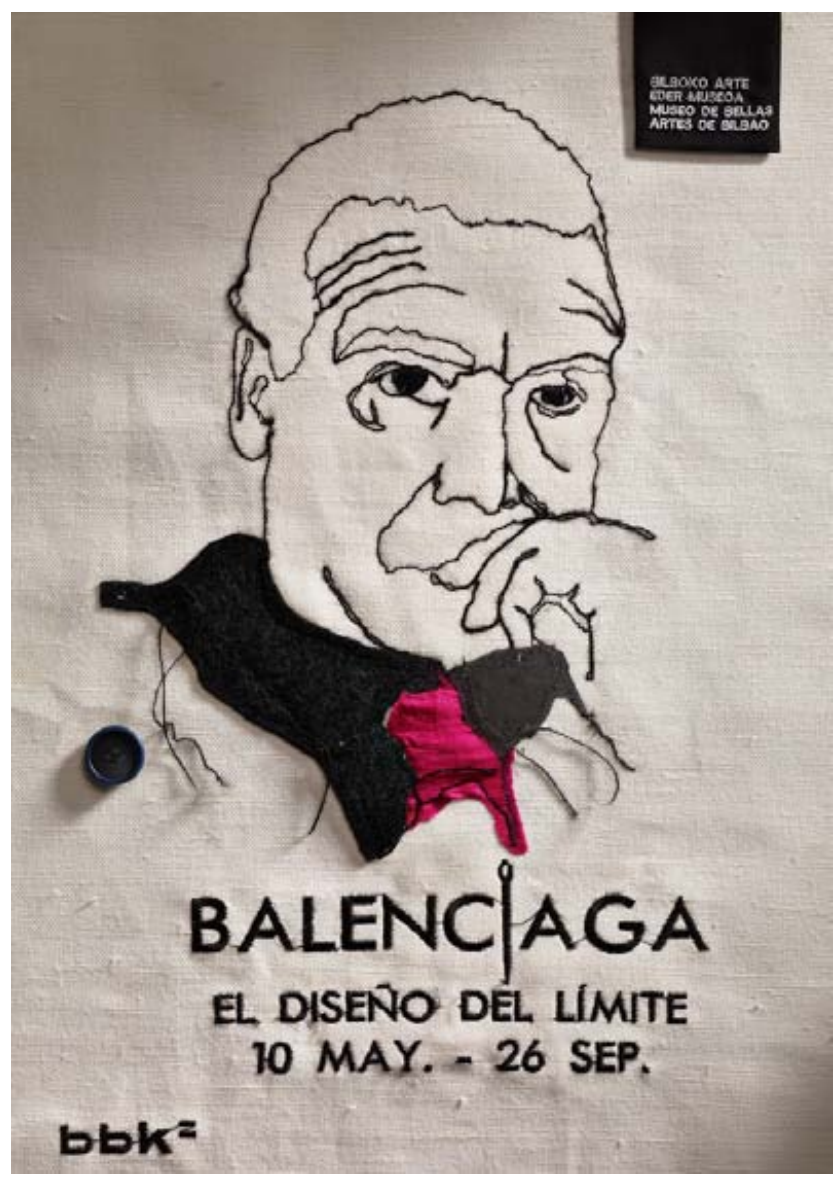

Fuente: Herederos de Rowan

El retrato del modisto y la información textual fue bordado sobre una toile, la tela que se utiliza para confeccionar los patrones. Pero no solo esto. Atención al juego tipográfico, con la sustitución de la «i» de Balenciaga por una aguja; y al logotipo del museo, a la manera de la etiqueta característica de una prenda de vestir. Pero tampoco esto es todo. Para los conocedores del diseñador se incluyó una 
muestra del «Botón Balenciaga»y el tipo de tela y colores que utilizaba normalmente (Fig. 14). Guiño sobre guiño.

Fig. 14. Detalle del cartel de la campaña «Balenciaga. El diseño del límite»

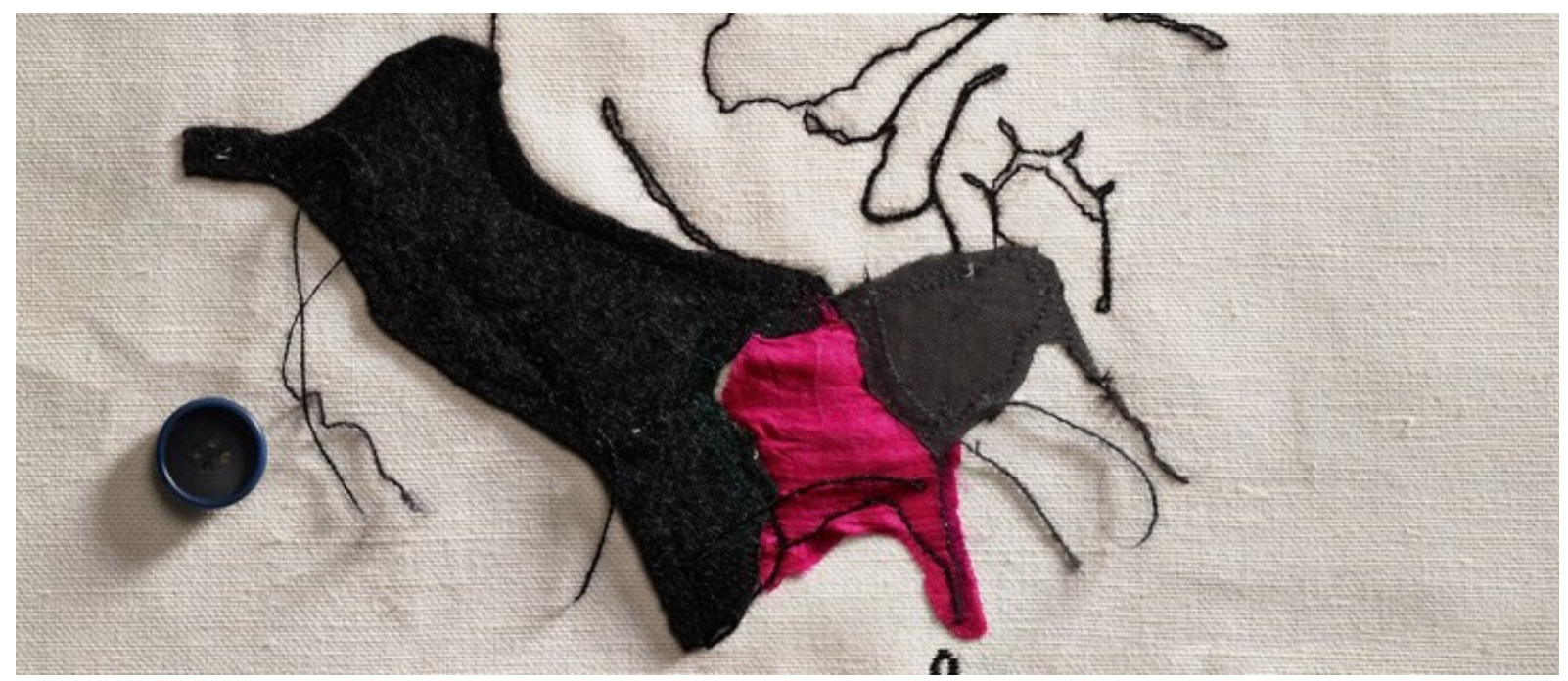

Fuente: Herederos de Rowan

Exquisitez e inteligencia. Como se comentó acertadamente en su momento, un anuncio que les salió bordado ${ }^{21}$. Sirviéndome del ya citado Manel Baena, se puede considerar una campaña de comunicación de alta costura, no de prêt-à-porter, como son la gran mayoría.

\subsection{Un ejemplo de uso de una figura retórica}

Un último ejemplo que forma parte de la excepción a la regla general fue la campaña publicitaria que puso en marcha, a principios del año 2010, la Fundació Antoni Tàpies (Barcelona) para dar a conocer su reapertura después de un largo y complicado proceso de reformas.

Sus responsables podían haberse limitado a informar de forma aséptica, pero fueron creativamente un poco más allá al servirse de una figura retórica: la paradoja. Como se puede comprobar (Figs. 15, 16 y 17), texto e imagen ofrecen mensajes contradictorios. Se acompaña un texto totalmente directo y contundente («Obrim», «Abrimos» en español) de una serie de imágenes que responden al momento en que el museo estaba en obras

21 Moreno, J. (2010): «El anuncio que salió bordado», Yorokobu, http://www.yorokobu.es/2010/05/07/el-anuncio-que-salio-bordado/. Web visitada el 24/05/2010. 
Figs. 15, 16 y 17. Muestras de la gráfica de la campaña «Abrimos»

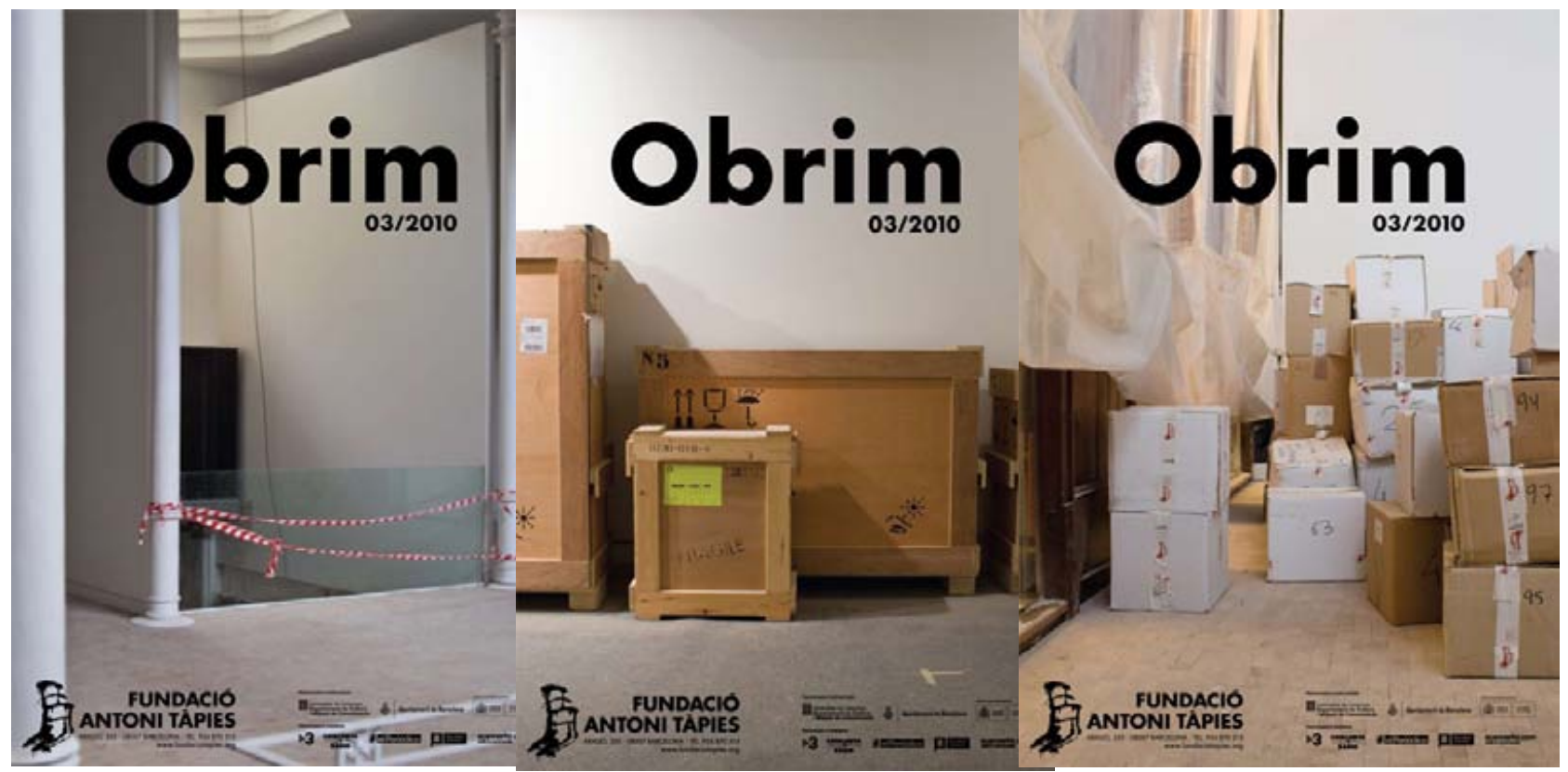

Fuente: Fundació Antoni Tàpies

Una paradoja que realmente sorprendía cuando el destinatario se topaba con las banderolas por el centro de Barcelona o con las postales que se utilizaron como un soporte publicitario más.

\section{Demostrando empíricamente el panorama actual}

Más allá de nuestra reflexión particular sobre la realidad de la publicidad utilizada para promocionar los museos y centros expositivos de arte españoles, hay que argumentarlo con datos científicos, lo que obliga a su demostración empírica.

Para conseguirlo, se utiliza como técnica de investigación el análisis de contenido de tipo cuantitativo, que permite una descripción objetiva, sistemática y cuantitativa de la realidad investigada ${ }^{22}$. En el caso que nos ocupa: la publicidad editada en España para promocionar los museos y centros de arte y las actividades culturales que estos organizan. La intención final es identificar y analizar este tipo de piezas publicitarias, pudiéndolas así agrupar en dos grandes grupos: denotativas y connotativas (Tabla 1).

La hipótesis principal es que, como ya vimos al principio, la publicidad que se edita en nuestro país para promocionar los museos y centros de arte y las activida-

22 BARdin, L. (1977): Análisis de contenido, Madrid, Ediciones Akal, 2002; KrIPPENDORF, K. (1980): Metodología de análisis de contenido. Teoría y práctica, Barcelona, Ediciones Paidós Ibérica, 1990. 
des culturales que estos organizan es fundamentalmente denotativa, siendo totalmente residual la utilización de la connotación.

Para aplicar esta opción metodológica de análisis de contenido y demostrar la hipótesis, se recurre a la revista especializada Descubrir el Arte (Arlanza Ediciones). Se trata de la revista de divulgación sobre la actualidad artística de mayor difusión en nuestro país, con periodicidad mensual y un promedio de tirada de 36.350 ejemplares ${ }^{23}$. Es igualmente uno de los soportes publicitarios más utilizados por el conjunto de museos y centros de arte de España.

Ya que nos interesa conocer la realidad actual, la muestra analizada se ciñe a los números publicados de Descubrir el Arte entre enero y diciembre de 2010; es decir, un total de 12 ejemplares ${ }^{24}$.

Para sistematizar y procesar la recopilación de datos, se creó una matriz cuyo objetivo primordial era recopilar todos los anuncios publicados ${ }^{25}$, agrupándolos después de un análisis detallado en uno de los dos grandes tipos de la retórica publicitaria: denotativo o connotativo.

Tabla 1. Resumen de la investigación

\begin{tabular}{l|l}
\hline Objetivo de la investigación & $\begin{array}{l}\text { Demostración del tipo de publicidad utiliza- } \\
\text { da para promocionar los museos de arte } \\
\text { españoles y sus actividades }\end{array}$ \\
\hline Metodología & Análisis de contenido cuantitativo \\
\hline Se analiza & Anuncios gráficos en prensa \\
\hline Soporte & Descubrir el Arte \\
\hline Muestra & 88 piezas gráficas \\
\hline Período & Enero-Diciembre 2010
\end{tabular}

Fuente: elaboración propia

Del total de 88 anuncios gráficos publicados en la revista para publicitar museos y centros de arte españoles y las actividades que organizan (Fig. 18), 78 de ellos responden a un planteamiento publicitario denotativo, mientras los 10 restantes se plantean con un determinado grado de connotación (Tabla 2). En resumen, un $89 \%$ de la muestra responde al tipo informativo, mientras sólo un $11 \%$ lo hace al persuasivo (Gráfico 1).

23 Datos de la Oficina de Justificación de la Difusión (OJD).

24 Del número 131 (Año XI) al 142 (Año XII).

25 Esos restos que, según Laurence Bardin, asimilan al analista de datos con un verdadero arqueólogo. BARDIN, L. (1977), op. cit., 29. 
Fig. 18. Muestra de una de las piezas publicitarias publicadas en Descubrir el Arte

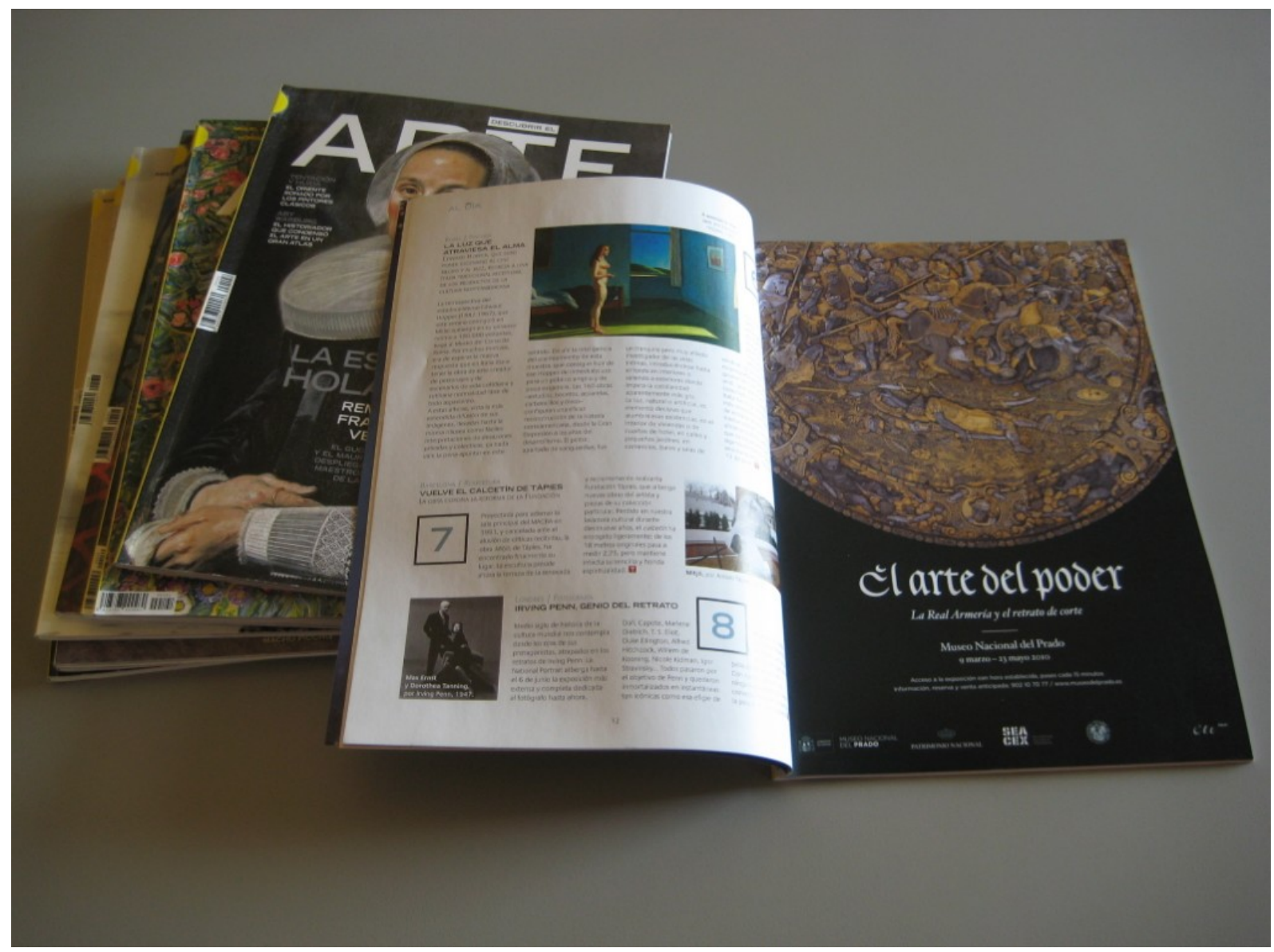

Fuente: elaboración propia

Tabla 2. Detalle de anuncios por número y tipo de retórica

\begin{tabular}{l|l|l|l}
\hline Número, fecha & Anuncios publicados & Denotativos & Connotativos \\
\hline 131, enero 2010 & 6 & 5 & 1 \\
\hline 132, febrero 2010 & 6 & 5 & 1 \\
\hline 133, marzo 2010 & 9 & 8 & 1 \\
\hline 134, abril 2010 & 5 & 5 & 0 \\
\hline 135, mayo 2010 & 11 & 10 & 1 \\
\hline 136, junio 2010 & 7 & 6 & 1 \\
\hline 137, julio 2010 & 11 & 10 & 1 \\
\hline 138, agosto 2010 & 6 & 5 & 1 \\
\hline 139, septiembre 2010 & 6 & 6 & 0 \\
\hline 140, octubre 2010 & 7 & 6 & 1 \\
\hline 141, noviembre 2010 & 7 & 6 & 1 \\
\hline 142, diciembre 2010 & 7 & 6 & 1 \\
\hline TOTAL & $\mathbf{8 8}$ & $\mathbf{7 8}$ & $\mathbf{1 0}$ \\
\hline
\end{tabular}

Fuente: elaboración propia 
Gráfico 1. Resumen porcentual del tipo de retórica utilizada

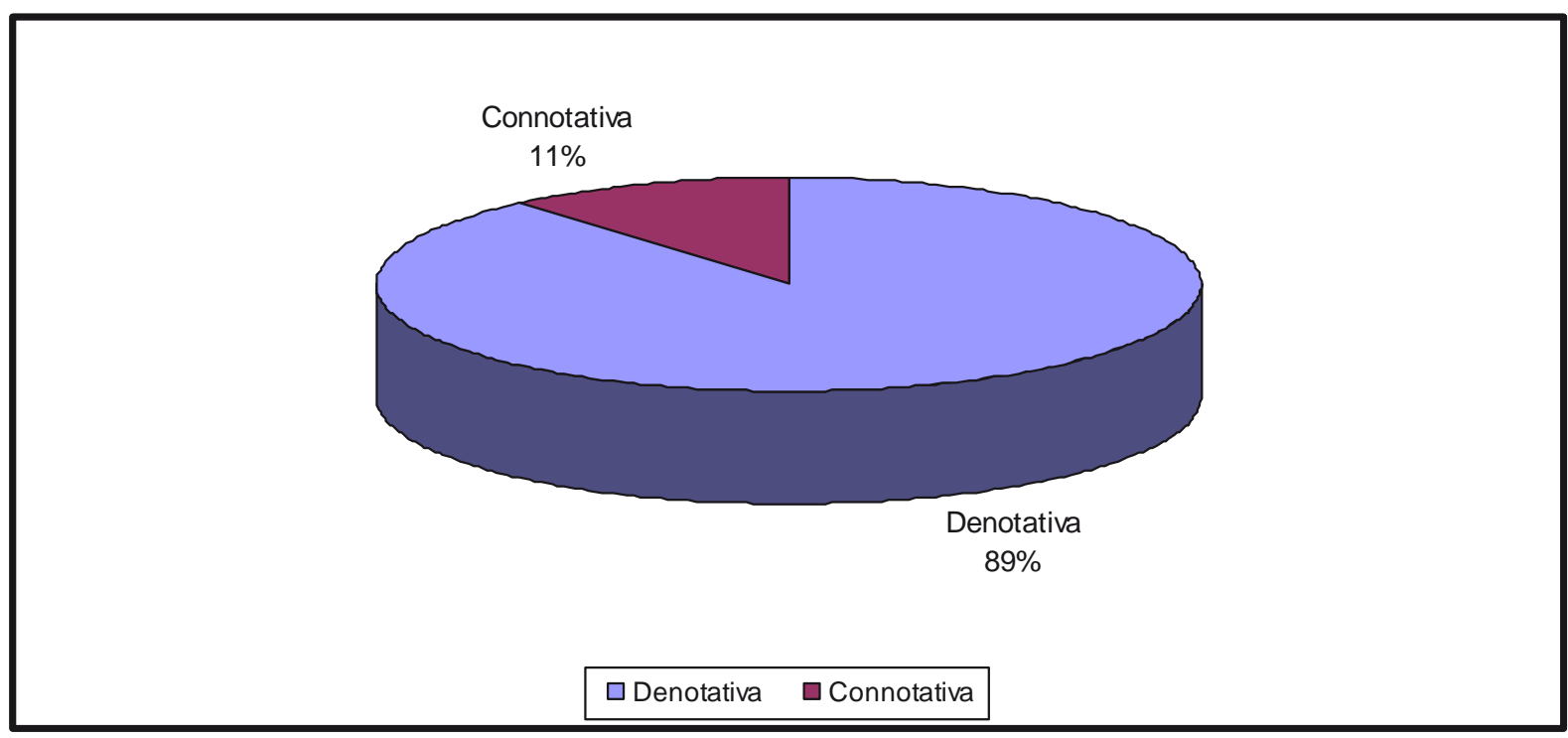

Los resultados finales de esta investigación empírica confirman totalmente nuestra intuición particular sobre el tema (expresada en las secciones 2 y 3) y la hipótesis de partida. Actualmente, una porción muy significativa de la publicidad producida para promocionar los museos y centros de arte de España es fundamentalmente denotativa, utilizándose muy poco la retórica connotativa.

\section{A modo de conclusión}

La simple existencia de las piezas comentadas en la sección 3 (junto con otras pocas que se han producido a los largo de los últimos años) demuestra que sí es posible que este ámbito cultural se sirva de una publicidad persuasiva-connotativa, acallando definitivamente las voces de aquellos que desde los museos españoles creen y/o afirman que sólo se puede/debe informar al público.

Sostener en la actualidad esta opinión supone una triple pérdida, tanto para los museos como para la propia publicidad y la Cultura.

Para la institución cultural, continuar pensando de esa manera es seguir aceptando la pérdida de oportunidades, al dilapidar potenciales visitantes interesados en sus actividades. Algo triste en general, pero lamentable si hablamos de museos públicos.

Para la publicidad, dicha actitud supone una doble pérdida, pues trabajar con una materia prima de tanta carga cultural la obliga a auto-exigirse un mayor nivel, sirviéndose «de recursos realmente ingeniosos, agudos y, por tanto, nada vulgares, 
para abrirse paso al interés del público» ${ }^{26}$. Lo cual también permite a los creativos publicitarios enfrentarse a retos mucho más sugerentes intelectualmente, acostumbrados como están a poner su creatividad al servicio de un papel higiénico más resistente o de un detergente para la ropa que lava mejor.

En conclusión, explotar y exprimir las potencialidades de la publicidad y de sus creativos es enriquecedor y beneficioso para todos, también para la Cultura. Anuncios memorables son los que nos hacen mejores y de paso enriquecen nuestra iconosfera visual. Pues guste o no, y como decía Bill Bernbach, los profesionales de la comunicación son formadores de la sociedad, capaces de vulgarizarla, brutalizarla o ayudarla para que suba de nivel ${ }^{27}$.

Para quien continúe pensando que la publicidad de museos debería seguir siendo adalid de la excepcionalidad, me permito el atrevimiento de acabar este artículo con una pregunta directa que les apela: ¿realmente quieren seguir empobreciéndonos?

\section{Referencias bibliográficas}

BAENA, M. (2009): «Salvaje (fauve) es la palabra que mejor define la campaña de comunicación de la exposición Kees Van Dongen pero, ¿cómo se llega a la elección de la imagen que será su leit motiv?», El Blog del Museu Picasso de Barcelona, http://www.blogmuseupicassobcn.org/es/2009/07/salvaje-fauve-es-la-palabra-quemejor-define-la-campana-de-comunicacion-de-la-exposicion-kees-van-dongen-pero$\%$ c2\%bfcomo-se-llega-a-la-eleccion-de-la-imagen-que-sera-su-leit-motiv/. Web visitada el 02/04/2010.

BARDIN, L. (1977): Análisis de contenido, Madrid, Ediciones Akal, 2002.

Benjamin, W. (1955): Dirección única, Madrid, Ediciones Alfaguara, 1987.

Diario De Sevilla (2009): «¿Está de acuerdo con la retirada del 'piercing' del cartel de la exposición del Joven Murillo?», diariodesevilla.es, http://www.diariodesevilla.es/encuesta/?int_PK=1777. Web visitada el 25/05/2010.

DÍAZ MEYER, G. (2008): «Aspectos de la comunicación visual y gráfica en la comunicación del patrimonio cultural», en Mateos Rusillo, S. (coord.), La comunicación global del patrimonio cultural, Gijón, Ediciones Trea, 175-269.

EguizÁBAL, R. (2007): Teoría de la publicidad, Madrid, Ediciones Cátedra.

FERNÁNDEZ LÓPEZ, S. (2007): Cómo gestionar la Comunicación. En organizaciones públicas y no lucrativas, Madrid, Narcea.

GARDE, V.; IZQUIERDO, I. (coord.) (2005): Criterios para la elaboración del Plan Museológico, Madrid, Subdirección General de Museos Estatales, Dirección General de Bellas Artes y Bienes Culturales, Ministerio de Cultura, http://www.mcu.es/museos/MC/PM. Web visitada el 02/04/2010.

26 Díaz Meyer, G. (2008): «Aspectos de la comunicación visual y gráfica en la comunicación del patrimonio cultural», en Mateos Rusillo, S. (coord.), La comunicación global del patrimonio cultural, Gijón, Ediciones Trea, 251.

27 Citado en Moliné, M. (1999): La fuerza de la publicidad. Saber hacer buena publicidad. Saber administrar su fuerza, Madrid, Cinco Días, 13. 
GuIRAO, Á. (2006): «¿Forma parte la publicidad de nuestro patrimonio cultural? (Publicidad y Patrimonio)», Tonos Digital. Revista electrónica de estudios filológicos, $\mathrm{n} .11$, http://www.um.es/tonosdigital/znum11/estudios/10-publicidad.htm. Web visitada el 02/04/2010.

GURREA, Á. (1999): Los anuncios por dentro, Bilbao, Servicio Editorial de la Universidad del País Vasco.

HoOPER-GREENHILL, E. (1994): Los museos y sus visitantes, Gijón, Ediciones Trea, 1998.

Hyland, A.; KING, E. (2006): c/id. Cultura e identidad. El arte de las marcas, Barcelona, Blume.

ICOM (2010): «Development of the Museum Definition according to ICOM Statutes (20071946)», http://icom.museum/hist_def_eng.html. Web visitada el 01/04/2010.

Kotler, N.; Kotler, P. (1998): Estrategias y marketing de museos, Barcelona, Editorial Ariel, 2001.

KRIPPENDORF, K. (1980): Metodología de análisis de contenido. Teoría y práctica, Barcelona, Ediciones Paidós Ibérica, 1990.

Moliné, M. (1999): La fuerza de la publicidad. Saber hacer buena publicidad. Saber administrar su fuerza, Madrid, Cinco Días.

MorenO, J. (2010): «El anuncio que salió bordado», Yorokobu, http://www.yorokobu.es/2010/05/07/el-anuncio-que-salio-bordado/. Web visitada el 24/05/2010.

Puig DE LA BellacASA, B. (2006): «Segmentación de públicos y estrategias de comunicación cultural», en Gómez de la Iglesia, R., La comunicación en la gestión cultural, Vitoria-Gasteiz, Grupo Xabide, 39-48.

RICARTE, J. M. (1998): Creatividad y comunicación persuasiva, Barcelona, Universitat Autònoma de Barcelona, Servei de Publicacions et alt.

RONDÓN, J. M. (2009): «Murillo con 'piercing'», elmundo.es, http://www.elmundo.es/elmundo/2009/10/03/andalucia_sevilla/1254567546.html. Web visitada el 25/05/2010.

SatuÉ, E. (2004): El diseño gráfico. Desde los orígenes hasta nuestros días, Madrid, Alianza Editorial.

VALdÉs SAGÜES, M. C. (1999): La difusión cultural en el museo: servicios destinados al gran público, Gijón, Ediciones Trea. 